\title{
Kemitraan Puskesmas dan Sekolah dalam Pencegahan Malaria pada Anak Usia Sekolah di Seluma Bengkulu
}

\author{
Hilza Novrinda ${ }^{1}$, Misnaniarti ${ }^{1}$, Rostika Flora ${ }^{1}$, HM. Zulkarnain ${ }^{2}$, Samwilson $^{3}$, Risnawati Tanjung ${ }^{4}$ \\ ${ }^{1}$ Fakultas Kesehatan Masyarakat Universitas Sriwijaya \\ ${ }^{2}$ Fakultas Kedokteran Universitas Sriwijaya \\ ${ }^{3}$ Fakultas Matematika dan Ilmu Pengetahuan Alam Universitas Bengkulu \\ ${ }^{4}$ Prodi Kesehatan Lingkungan Politeknik Kesehatan Kemenkes RI Medan
}

\section{ABSTRACT}

Background: The partnership between Puskesmas (Community Health Center) and school to improve the health of school-age children known as the Trias school health unit. In Seluma only $7.69 \%$ of schools have a room for health school program. This study aims to explore the partnership between Puskesmas' and schools in malaria prevention to school-age children in Seluma.

Method: This study used qualitative research with phenomenological approach. It was conducted in April 2019. The main informants consisted of 5 teachers, from 5 elementary schools and 2 UKS staff Puskesmas from Puskesmas Puguk and Puskesmas Talang Tinggi, who have worked over than three years. The data collected by indepth interview, FGDs and observation.

Results: The role of the UKS Puskesmas staffs was not optimal in carrying out the triad UKS activities. They only carry out routine UKS activities. Partnership between Puskesmas and schools has not been implemented optimally. It is still very limited action to cooperate the routine triad implementation from the Puskesmas and schools. A review needs to be done to assess the performance of the UKS, especially through healthy school competition activities.

\section{Correspondence}

hilzanovrinda@gmail.com

\section{Article History}

Received 10 July 2019

Revised 30 January 2020

Accepted 16 January 2020

Available Online 6 March 2020

\section{Keywords}

Partnership

Puskesmas

Primary school

School health unit (UKS)

\section{DOI}

10.14710/jpki.15.1.9-15

\section{PENDAHULUAN}

Kemitraan merupakan suatu kerjasama formal antara individu-individu, kelompok-kelompok atau organisasiorganisasi untuk mencapai suatu tujuan tertentu. ${ }^{1}$ Kemitraan antara puskesmas dan sekolah dilakukan melalui program yang digiatkan untuk meningkatkan derajat kesehatan pada anak usia sekolah. Program kemitraan tersebut lebih dikenal dengan Trias Usaha Kesehatan Sekolah (Trias UKS). Kegiatan trias UKS ini terdiri dari pendidikan kesehatan, pelayanan kesehatan dan pembinaan lingkungan sekolah. Kemitraan yang dilakukan antara puskesmas dan sekolah dalam program UKS diantaranya dalam penyusunan rencana kegiatan UKS tahunan. Pada tahap pelaksanaan antara puskesmas dan sekolah melakukan sesuai tugas dan tanggung jawabnya, seperti pelayanan kesehatan lebih banyak dilakukan pihak puskesmas dibanding sekolah. Tahap monitoring dilakukan bersama-sama antara puskesmas dan sekolah sesuai dengan instrumen monitoring. $^{2}$

Kasus malaria di dunia lebih dari $70 \%$ terjadi pada penduduk dengan tingkat ekonomi rendah. Prevalensi malaria yang terjadi pada anak-anak di dunia selama tahun 2017 sebesar $61 \%$. $^{3}$ Kasus malaria di Indonesia mengalami penurunan namun masih dinilai tinggi. Prevalensi malaria di 15 provinsi masih diatas angka nasional, sebagian besar berada di wilayah Indonesia Timur (Papua 28,6\%, NTT 23,3\%, Papua Barat 19,4\%, Sulawesi Tengah 12,5\% dn Maluku 10,7\%). Angka positif malaria juga didapatkan pada kelompok rentan anak-anak umur 1-9 tahun dan ibu hamil sebesar 1,9\%. Proporsi positif malaria pada penduduk pedesaan sekitar dua kali lipat lebih banyak sebesar 1,7\% dibandingkan dengan penduduk perkotaan $(0,8 \%) .{ }^{4}$ Kasus malaria pada anak usia sekolah di Indonesia sebanyak $27 \%$. Sedangkan di Provinsi Bengkulu proporsi malaria pada anak sebesar $21 \%$. Data pasti kejadian infeksi malaria pada anak usia sekolah tidak ada dalam profil kesehatan Kabupaten Seluma, sehingga data rujukan yang digunakan adalah proporsi malaria pada anak usia sekolah di provinsi Bengkulu. Angka kesakitan malaria (API) di Provinsi Bengkulu sebesar 0,53 per 1000 penduduk. ${ }^{5}$

Beberapa upaya yang umum disosialisasikan efektif untuk mencegah malaria diantaranya tidur dengan menggunakan kelambu, melakukan penyemprotan pada dinding rumah dan atau mengoleskan repellent sebelum tidur. ${ }^{6}$ Kegiatan tersebut dapat dilakukan melalui pendidikan kesehatan yang ada dalam trias UKS dengan penyuluhan 
kepada anak didik di sekolah. Saat ini di Seluma ada 182 sekolah dasar dan ada 115 sekolah yang telah membentuk UKS, namun hanya $7,69 \%$ UKS yang terdaftar di kementerian pendidikan dan kebudayaan yang memiliki ruang $\mathrm{UKS}^{7}$

Keberhasilan kegiatan trias UKS di sekolah tidak lepas dari peran seorang guru yang bertanggung jawab dalam mengelola UKS. Guru memberi pengaruh besar dalam perubahan sikap anak didik selama di lingkungan sekolah. Beberapa peran guru UKS diantaranya menanamkan kebiasaan hidup bersih dan sehat pada siswa; mengawasi dan melakukan pemeriksaan kebersihan anak didik secara berkala; melakukan pengawasan dan pemeriksaan kebersihan lingkungan; melakukan pertolongan pertama dan pengobatan ringan sesuai kemampuanya; mengenal tanda dan gejala penyakit menular serta masalah yang ditimbulkan, dan juga tahu apa saja tindakan selanjutnya yang dapat dilakukan; mengamati tingkah laku para siswa. ${ }^{2}$

Kegiatan UKS yaitu penyuluhan kesehatan dan pendidikan kesehatan dilaksanakan secara bersama-sama dengan Puskesmas. Selain kegiatan promosi kesehatan dilakukan juga penjaringan kesehatan sekali dalam setahun, pelayanan kesehatan 1 kali dalam setahun, pemberian obat cacing, imunisasi, pemeriksaan gigi dan mulut, pemeriksaan status gizi anak tersebut. Beberapa hal yang seharusnya dilakukan oleh tenaga Puskesmas, dalam upaya pelaksanaan trias UKS diantaranya adalah sosialisasi dan memberikan dukungan aktif ataupun pembelaan (advokasi); menyiapkan SDM melalui pembinaan kader kesehatan sekolah, pendidik sebaya, konselor sebaya; berkoordinasi dengan lintas program dan lintas sector dalam upaya mengatasi masalah kesehatan di sekolah; melakukan peningkatan peran serta aktif warga sekolah dalam mengatasi masalah kesehatan; menyiapkan sarana dan prasarana baik untuk UKS di sekolah maupun UKS di Puskesmas. ${ }^{8}$

Akan tetapi menurut Dinas Pendidikan Kabupaten Seluma peran antara guru dan petugas Puskesmas belum maksimal terlaksana pada sekolah dasar di kabupaten Seluma. ${ }^{9}$ Untuk itu penelitian ini dilaksanakan untuk mengetahui bagaimana kemitraan antara Puskesmas dan sekolah dalam mencegah Malaria pada anak usia sekolah di kabupaten Seluma.

\section{METODE}

Penelitian ini menggunakan desain kualitatif dengan pendekatan fenomenologi dan dilaksanakan pada bulan April 2019 di lima sekolah dasar yaitu SD 9, SD 23, SD 110, SD 10 dan SD 78 dan dua Puskesmas yang dipilih dari lima kecamatan dengan kasus malaria tertinggi di Seluma yaitu Puskesmas Puguk dan Puskesmas Talang Tinggi. Penentuan informan menggunakan purposive sampling. Penentuan informan guru UKS dipilih berdasarkan kriteria: bersedia menjadi informan dan berasal dari sekolah yang pernah mengikuti lomba sekolah sehat. Pengelola UKS Puskesmas sebagai informan triangulasi dipilih berdasarkan masa kerja. Masa kerja tiga tahun diambil dari masa kerja petugas Puskesmas yang paling lama (> 3 tahun). Masa kerja mempengaruhi kinerja seseorang dalam bekerja. Masa kerja dapat dilihat dari berapa lama masa kerja atau pengabdian setiap pegawai yang memiliki rasa tanggung jawab, rasa ikut memiliki dan keberanian dalam kelangsungan hidup yang dapat mempengaruhi produktivitas tenaga kerja. ${ }^{10,11}$

Pengumpulan data dengan wawancara mendalam dilakukan pada 2 orang petugas Puskesmas yang bertugas mengelola program UKS di Puskesmas dan FGD dilakukan pada 5 orang guru SD yang bertugas mengelola UKS di sekolah. Tujuan FGD dan wawancara mendalam adalah untuk memperoleh informasi yang berhubungan dengan pelaksanaan kemitraan antara Puskesmas dan sekolah dalam pencegahan penyakit malaria pada anak usia sekolah di Kabupaten Seluma.

\section{HASIL DAN PEMBAHASAN}

Sebagian besar informan berjenis kelamin perempuan dengan masa kerja kurang dari 3 tahun. Karakteristik informan terlihat pada tabel 1 di bawah ini.

Tabel 1. Gambaran karakteristik informan FGD dan wawancara mendalam

\begin{tabular}{cccc}
\hline Kode & $\begin{array}{c}\text { Jenis } \\
\text { kelamin }\end{array}$ & Jabatan/ pekerjaan & $\begin{array}{c}\text { Masa kerja } \\
\text { (tahun) }\end{array}$ \\
\hline Yn & $\mathrm{P}$ & Guru UKS & $>3$ \\
$\mathrm{Ws}$ & $\mathrm{L}$ & Guru UKS & $>3$ \\
$\mathrm{~Np}$ & $\mathrm{P}$ & Guru UKS & $\leq 3$ \\
Ys & $\mathrm{P}$ & Guru UKS & $\leq 3$ \\
$\mathrm{In}$ & $\mathrm{P}$ & Guru UKS & $\leq 3$ \\
$\mathrm{Zn}$ & $\mathrm{P}$ & Petugas UKS & $\leq 3$ \\
& & Puskesmas & $\leq 3$ \\
$\mathrm{Me}$ & $\mathrm{P}$ & Petugas UKS & $\leq$ \\
& & Puskesmas & \\
\hline
\end{tabular}

Dari hasil FGD didapat bahwa seluruh informan mengatakan bahwa UKS itu sangat perlu dibentuk dan diadakan di sekolah, dengan alasan yang sama umumnya untuk memberikan pelayanan pada anak yang sedang sakit. Begitupun dengan petugas Puskesmas yang sudah memahami dengan tugasnya sebagai pengelola UKS di Puskesmas.

\section{MoU UKS}

Puskesmas dan sekolah sudah memiliki MoU tentang UKS. Namun masih ada beberapa sekolah yang belum memiliki MoU. Sekolah yang sudah terakreditasi pasti memiliki MoU karena itu syarat dalam standar akreditasi sekolah dan biasanya sekolah akan memperpanjang MoU 
bila akan dilakukan penilaian akreditasi.

Ikatan kerjasama atau MoU (Memorandum of Understanding) merupakan dokumen persetujuan formal antara antara dua belah pihak atau lebih. Perusahaan atau organisasi menggunakan MoU untuk menyepakati dan mempertahankan kerjasamanya. ${ }^{1}$

Berdasarkan hasil telaah dokumen, isi MoU yang telah disusun antar Puskesmas dan sekolah masih bersifat secara umum meliputi kegiatan Trias UKS apa saja yang merupakan tugas masing-masing pihak sesuai dengan pedoman UKS yang telah ditetapkan. MoU khusus untuk pencegahan dan pemberantasan malaria pada anak usia sekolah dasar belum ada dan belum pernah dibuat.

\section{Sarana dan Prasarana UKS}

Dalam hal sarana dan prasarana, Tim Pembina UKS Pusat telah menetapkan standar sarana prasarana UKS yaitu : a) Kategori sarana dan prasarana sederhana, jika sudah memiliki : tempat tidur lengkap dengan kasur, timbangan untuk mengukur berat badan, alat ukur tinggi badan, alat periksa mata (Snellen Chart), kotak P3K lengkap dengan obat-obatan sederhana seperti obat untuk luka, obat diare, obat turun panas, kassa pembalut, plester. b) Sarana dan Prasarana Lengkap, jika tiga kriteria sederhana sudah dimiliki dan dilengkapi lagi dengan: lemari obat, buku rujukan kartu menuju sehat, poster-poster tentang kesehatan, struktur organisasi UKS, jadwal piket dokter kecil, tempat cuci tangan/wastafel, data kesakitan anak didik. ${ }^{2}$

Pada penelitian ini sekolah belum melengkapi kebutuhan perabot UKS misalnya ketersediaan lemari obat, tempat cuci tangan/wastafel, kartu menuju sehat anak sekolah, dan beberapa perlengkapan lainnya yang telah ditetapkan. Guru UKS tersebut sangat mengharapkan adanya bantuan dari pihak luar terkait kelengkapan UKS khususnya ruangan tersendiri untuk UKS. Sekolah sudah sangat mendukung adanya UKS terbukti dari beberapa sekolah walaupun tidak ada ruangan khusus, pihak sekolah tetap membuat tempat UKS yang umumnya berbagi dengan ruang perpustakaan ada yang menggunakan hordeng dan ada pula lemari sebagai pembatasnya. Hal ini dikarenakan masih kurangnya infrastruktur di sekolah berupa ruang belajar, sehingga ruangan yang ada lebih diprioritaskan untuk kegiatan belajar mengajar, seperti kutipan berikut ini:

"untuk ruangan tersendiri khusus UKS belum ada bu, kami buat UKS diruang perpustakaan, obat-obatan kami beli sendiri" (Yn).

"untuk sekarang belum punya bu, karena ruangannya dipakai untuk belajar, dulu bergabung dengan perpustakaan.... jadi anak-anak yang sakit terpaksa istirahat di kantor..." (In).
Menurut Hidayat dan Maryam yang dikutip oleh Nurhayu, mengatakan bahwa kelengkapan sarana dan prasarana UKS perlu ditingkatkan sebagai penunjang untuk kegiatan Trias UKS terutama untuk pelayanan kesehatan serta pembinaan lingkungan sekolah sehat. ${ }^{12}$

Salah satu trias UKS adalah pendidikan kesehatan yang dilaksanakan oleh guru melalui penyuluhan yang disampaikan pada jam pelajaran. Seperti yang disampaikan oleh salah satu informan berikut ini:

"kalau kami dari guru, biasanya setiap habis pelajaran ada waktu luang diselipkan penyampaian seperti jangan lupa cuci tangan sebelum makan... jangan lupa bersihkan rumah, jangan biarkan pakaian yang banyak bergantungan karena bisa jadi sarang nyamuk... yang rutin tiap minggu tu periksa kebersihan kuku setiap hari senin"( $Y n)$.

Penyuluhan kesehatan ini dapat lebih optimal apabila dilengkapi dengan sarana dan prasarana seperti posterposter, leaflet maupun brosur-brosur tentang pencegahan penyakit menular khususnya malaria. Hal ini sejalan dengan penelitian Karkada yang mengungkapkan tentang promosi kesehatan di sekolah. Dimana kegiatan tersebut akan efektif pada anak usia sekolah melalui poster-poster, leaflet maupun brosur. ${ }^{13}$ Media tersebut dapat digunakan saat pelaksanaan penyuluhan kesehatan ataupun pembelajaran di sekolah. Peralatan tersebut akan lebih bermanfaat dan aman bila disimpan dalam ruangan khusus untuk UKS yang nyaman. ${ }^{14}$

Kelengkapan sarana dan prasarana termasuk dalam kemitraan Puskesmas dan sekolah, hal tersebut merupakan tanggung jawab dari Puskesmas sebagai tim pelaksana teknis UKS. Ada beberapa hal yang seharusnya dilakukan oleh tenaga Puskesmas, dalam upaya pelaksanaan trias UKS, salah satu diantaranya adalah menyiapkan sarana dan prasarana baik untuk UKS di sekolah maupun UKS di Puskesmas.

Hasil wawancara terhadap guru didapat bahwa selama ini Puskesmas hanya membantu dalam kelengkapan obat-obatan, sedangkan untuk fasilitas lainnya dilimpahkan kepada sekolah. Hal ini juga diakui oleh petugas Puskesmas, bahwa mereka untuk saat ini hanya memfasilitasi penyediaan obat-obatan ringan dan pelayanan rujukan. Seperti kutipan berikut ini:

"kami hanya membantu penyediaan obat saja bu, itupun obat-obatan ringan seperti obat sakit perut, obat penurun panas, obat sakit kepaa, oralit, betadhin, pester, perban, kalau anak-anak sakitnya tambah parah nanti dibawa sama gurunya ke Puskesmas.."( Me). 


\section{Pencegahan Penyakit Infeksi Malaria}

Pelaksanaan pencegahan malaria melalui trias UKS oleh pihak puskemas dan sekolah umumnya selalu dilaksanakan secara serentak dengan penanggulangan demam berdarah, hal ini menurut mereka dikarenakan tindakan yang dilakukan itu sama, diantaranya adalah pemberantasan sarang nyamuk dengan penyemprotan sekitar lingkungan sekolah, mencegah gigitan nyamuk dengan pemakaian kelambu atau lotion anti nyamuk atau obat nyamuk saat tidur, seperti dalam petikan ungkapan berikut ini:

"kalau untuk malaria aja belum ada bu, biasanya sekalian dengan demam berdarah, kareno hampir sama kan caronyo.. biasanya penyemprotan di sekitar kelas, sampah-sampah dibersihkan jangan sampai ada air berendam, itu ado jentik-jentik katonyo, kami bersihkan halaman, siring, bersihkan wc, kuras bak mandi..kalau ado botol-botol bekas langsung dibuang.. "( $\mathrm{Np}$ ).

"kalau untuk pencegahan malaria yang ada di tempat kami tu pernah penyemprotan ke ruang-ruang kelas kantor wc/kamar mandi, bersihkan sampah-sampah yang tegenang air..tapi itu biasanya sekalian dengan demam berdarah,,bukan khusus untuk malaria saja.."(Ws)

Guru biasanya melakukan transfer ilmu tentang pencegahan malaria pada saat jam pelajaran. Materi yang disampaikan masih bersifat umum seperti memakai kelambu saat tidur, menggunakan lotion anti nyamuk ataupun penyemprotan sebelum tidur. Peran petugas Puskesmas disini adalah menyampaikan sosialisasi mengenai pencegahan malaria, melakukan pembinaan terhadap lingkungan sekolah berupa pemberantasan sarang nyamuk melalui fogging. Pada saat dilakukan penelitian ini ternyata di Seluma belum pernah dilakukan screening malaria pada anak usia sekolah sebagai salah satu bentuk kegiatan dalam pelayanan kesehatan Trias UKS.

Guru UKS ikut berperan serta dalam meningkatkan derajat kesehatan anak usia sekolah. Melalui kegiatan UKS diharapkan dapat meningkatkan kemampuan hidup sehat anak sehingga dapat membentuk perilaku hidup sehat pada anak usia sekolah. Hal tersebut dapat dilakukan guru melalui pendidikan kesehatan dengan memberikan pengetahuan kepada siswa di sekolah yang ada hubungannya dengan masalah-masalah kesehatank hususnya tentang pencegahan terhadap malaria, sehingga mereka diharapkan dapat mempraktikkan gaya hidup sehat dimanapun mereka berada. Melalui program yang dijalankan oleh UKS, diharapkan siswa mempunyai pengetahuan, sikap dan cara praktik yang sesuai dengan kesehatan. ${ }^{15}$

\section{Pendidikan dan Pelatihan Guru UKS}

Para guru UKS ternyata belum pernah mendapatkan pelatihan tentang UKS apalagi tentang malaria. Berdasarkan hasil diskusi, pelatihan ini sangat mereka butuhkan supaya mereka lebih memahami tentang UKS yang benar, bagaiman sistem pelaporan UKS itu, apa saja kegiatan yang sebaiknya dilakukan oleh UKS di sekolah, jika ada masalah tentang UKS di sekolah kemana mereka harusnya melaporkan. Begitupun tentang malaria, selama ini mereka hanya mendapatkan informasi dari media elektronik. Informan juga berharap walaupun tidak ada pelatihan minimal ada pertemuan rutin tentang UKS untuk membahas masalahmasalah yang dihadapi oleh UKS di sekolah.

"kalau untuk kami guru UKS belum pernah ada pelatihan tentang UKS, jangankan pelatihan seminar atau pertemuan rutin aja dak pernah dilibatkan, apolagi pelatihan tentang malaria, belum pernah bu" $(Y s)$

Petugas Puskesmas juga mengatakan bahwa Puskesmas maupun dinas kesehatan belum pernah mengadakan pelatihan yang berkaitan dengan UKS untuk petugas UKS di Puskesmas maupun guru UKS di sekolah. Pihak Puskesmas hanya mengadakan sosialisasi dalam memberikan ilmu-ilmu baru tentang UKS ke sekolah.

Pengetahuan seseorang juga dapat dipengaruhi oleh sering tidaknya mengikuti pendidikan dan pelatihan ataupun bimbingan teknis tentang materi yang mereka butuhkan. Kementerian kesehatan melakukan kegiatan evaluasi pelaksanaan Trias UKS di 10 provinsi dengan tiga komponen utama pada sumber daya manusia, manajemen, dan sarana prasarana. Hasil evaluasi yang dilaksanakan Kementerian Kesehatan menunjukkan bahwa pada elemen sumber daya manusia ditemukan masih banyak guru pembina UKS yang belum mendapatkan pelatihan, Kepala Sekolah dan Madrasah tidak menunjang UKS, kurangnya motivasi guru sebagai pelaksana UKS karena belum ada angka kredit untuk guru pembina UKS, belum ada buku pedoman materi kesehatan untuk pegangan guru, dan masih banyak tenaga kesehatan yang belum dilatih UKS. ${ }^{9}$

\section{Pembinaan UKS}

Pembinaan dan pengembangan UKS hendaknya harus selalu dilaksanakan secara terpadu, terarah, terencana dan merupakan tanggung jawab pihak kesehatan dan pendidikan secara bersama-sama, dalam menanamkan, menumbuhkan, mengembangkan, serta membimbing anak didik dalam berperilaku hidup bersih dan sehat. ${ }^{16}$

Pembinaan UKS ke sekolah-sekolah dari Puskesmas saat ini sudah berjalan dengan cukup baik, dimana petugas UKS Puskesmas selalu melakukan pembinaan ke sekolah setiap tahunnya minimal sekali dalam setahun. Hal-hal yang dilakukan saat pembinaan biasanya memeriksa kondisi sumber air bersih, tempat cuci tangan, kondisi tempat sampah serta jumlah tempat sampah apakah masih layak digunakan atau tidak, serta kebersihan kelas, WC dan kantin. Kegiatan tersebut minimal dilakukan sekali setahun oleh 
Puskesmas. Hal ini terungkap dalam diskusi berikut:

"kalau SD kami ada didatangi orang puskesmas untuk evaluasi samo pembinaan bu, mereka melihat kebersihan WC, jumlah tempat sampah yang masih bagus cukup dak untuk satu sekolah, kebersihan kelas dan lingkungan sekolah, terus tempat cuci tangan, kondisi sumur bersih dak ada tutup dak, ," $(\mathrm{Np})$

"biasanya kita datang pas penjaringan atau pemeriksaan berkala, kalau untuk pembinaan ke sekolah biasanya kami pantau kebersihan sekolah, tempat cuci tangan, wc, air untuk di wc lancar atau tidak, makanan yang dijual di kantin, kami juga pantau spal, sama tempat pembuangan sampah baik yang kotak sampah di tiap ruangan ataupun tempat pembuangan sampah ---tempat cuci tangan umumnya pakai kran biasa didekat wc atau sumur" (Me).

Pada penelitian ini guru tidak pernah dilibatkan dalam perencanaan kegiatan UKS. Kerjasama antara Puskesmas dan sekolah biasanya terjadi saat adanya kunjungan dari Puskesmas. Sejalan dengan yang diungkapkan oleh petugas UKS di Puskesmas yang mengatakan bahwa perencanaan kegiatan UKS yang dilakukan saat ini tidak pernah melibatkan sekolah. Pihak Puskesmas juga mengatakan bahwa untuk pelatihan tentang UKS belum pernah dilakukan dikarenakan belum tersedianya adanya dana khusus pelatihan tersebut. Sehingga dapat disimpulkan bahwa kemitraan antara Puskesmas dan sekolah pada penelitian ini terjadi saat Puskesmas mengadakan kunjungan ke sekolah.

Sejalan dengan penelitian Muzakkiroh, kemitraan antara Puskesmas dan sekolah sangat diperlukan dalam pelaksanaan trias UKS. Tim UKS Puskesmas dan sekolah mempunyai tugas masing-masing dalam pelaksanaan trias UKS tersebut, namun setiap pelaksanaanya tetap harus saling berkoordinasi. Hasil penelitian Muzakkiroh mengatakan bahwa Puskesmas melakukan kegiatan diluar rutinitas UKS apabila adanya permintaan dari sekolah, dan itupun dana disiapkan oleh pihak sekolah. ${ }^{17}$

Kerjasama tidak akan terwujud tiba-tiba, namun harus dibangun secara sadar dan dengan perencanaan yang matang. Melalui kerjasama antar sekolah dan lintas sektor lainnya akan terjadi pertukaran informasi terhadap masalah dan fenomena yang sedang terjadi baik di lingkungan sekolah, keluarga maupun masyarakat. ${ }^{18}$

Kemitraan antara puskesmas dan sekolah dapat juga terjadi saat penyusunan kurikulum pendidikan, dengan adanya materi tentang pendidikan kesehatan dalam salah satu pelajaran akan menyebabkan terjadinya penyebaran informasi tentang kesehatan dari guru kepada anak didiknya. Sehingga diharapkan dapat mengubah perilaku hidup bersih dan sehat pada anak didik seperti tidak merokok, menjauhi narkoba, menjauhi alkohol dan zat adiktif lainnya serta menjauhi perilaku seks bebas. Hal ini sudah dilakukan oleh pihak pendidikan di Inggris yang mewajibkan pendidikan kesehatan dalam kurikulum pendidikan di Negara mereka. Dan hal tersebut didukung oleh semua orang tua yang khawatir terhadap komunitas pergaulan anak-anak yang selalu dipengaruhi oleh media elektronik. ${ }^{19}$

Petugas UKS Puskesmas mengakui mereka belum maksimal melakukan kerjasama dengan pihak sekolah dalam kegiatan UKS ini. Pihak Puskesmas dan sekolah belum pernah menyusun rancangan kegiatan UKS secara bersamasama baik itu perencanaan, maupun monitoring dan evaluasi. Selama ini kegiatan yang sering dilakukan secara bersama hanya pada kegiatan pelayanan kesehatan yang rutin dilakukan sekali setahun seperti imunisasi, pemberian obat cacing, penjaringan dan pemeriksaan berkala pada anak sekolah. Petugas UKS Puskesmas juga menyadari masih banyak kekurangan dalam kegiatan UKS ini khususnya untuk pembinaan ke sekolah-sekolah. Hal ini dikarenakan keterbatasan dana pada anggaran di Puskesmas. Hal ini sejalan dengan penelitian sebelumnya di mana terdapat hubungan antara fungsi perencanaan dengan ketercapaian target angka cakupan indikator suatu program. Fungsi manajemen program memiliki pengaruh terhadap ketercapaian target angka cakupan suatu program. ${ }^{20}$

Menurut pedoman UKS dari tim Pembina pusat, pihak Puskesmas berkewajiban untuk melaksanakan dan mengadakan pelatihan serta bimbingan teknis tentang UKS dan masalah kesehatan lainnya ke sekolah secara rutin. Kegiatan tersebut bisa berupa pelatihan terhadap dokter kecil, pelatihan khusus untuk guru UKS, pembinaan tentang ruang UKS serta kelengkapan sarana prasarana UKS yang benar, dan bagaimana cara pelaporan kegiatan UKS yang baik dan benar. Jika hal tersebut dilaksanakan dengan baik maka tujuan akhir program UKS dapat tercapai. ${ }^{16}$

Sejalan dengan penelitian sebelumnya yang mengatakan bahwa fungsi pengawasan berpengaruh terhadap pencapaian cakupan keberhasilan suatu program. Pelaksanaan trias UKS di sekolah secara umum saat ini masih banyak hambatan dan rintangan. ${ }^{21,22}$ Termasuk dalam masalah pencegahan malaria. Dari hasil diskusi didapat bahwa kendala yang dialami selama informan mengelola UKS di sekolah diantaranya sarana dan biaya, selain mengelola UKS para informan juga tetap ada tanggung jawab sebagai guru yang wajib menyelesaikan materi pelajaran yang merupakan tugas utama sebagai seorang guru. Selain itu kendala yang mereka hadapi juga kurangnya pelatihan maupun pertemuan yang berhubungan dengan UKS baik dari pihak kesehatan maupun dinas pendidikan. Umumnya masalah yang ada di setiap sekolah adalah bantuan dana untuk UKS di sekolah dan diadakannya pelatihan dan pertemuan tentang UKS setiap tahun.

Selama ini tidak pernah ada penilaian untuk kinerja UKS, laporan yang ada di dinas kesehatan hanya sebatas tersedianya UKS dan tidak. Setiap diadakannya lomba sekolah sehat tidak ada penilaian khusus untuk UKS, 
penilaian masih bersifat ke sanitasi lingkungan sekolah. Khusus untuk guru yang mengelola UKS belum ada penghargaan tersendiri. Menurut peneliti perlu dikaji ulang tentang reward terhadap guru dan petugas UKS Puskesmas yang melaksanakan tugas ini sebagai tugas tambahan, hal tersebut bisa berupa honorarium atau dalam bentuk nilai pada kredit point yang dapat digunakan untuk menambah nilai kenaikan pangkat/jabatan.

Keberhasilan pelaksanaan UKS bukan hanya tanggung jawab bidang kesehatan, namun harus ada kerjasama dan kemitraan yang solid dari berbagai pihak dalam hal ini yang sangat berhubungan erat adalah pihak kesehatan dan sekolah. Kemitraan sekolah dengan Puskesmas perlu ditumbuhkan, dikembangkan dan dipelihara karena adanya masalah dan tantangan yang dihadapi sekolah dalam upaya untuk memberikan pelayanan kesehatan yang berkualitas prima. Pada prinsipnya kemitraan sekolah dengan Puskesmas menunjukkan adanya keinginan untuk berbagi tanggung jawab yang diwujudkan melalui perilaku hubungan di mana semua pihak yang terlibat saling membantu untuk mencapai tujuan bersama. ${ }^{23}$

\section{KESIMPULAN}

Peran petugas UKS Puskesmas belum optimal dalam melaksanakan kegiatan trias UKS. Dengan kata lain, petugas belum melakukan tugasnya sebagai pengelola UKS dengan hasil yang terbaik, petugas hanya melaksanakan kegiatan rutin UKS yang telah ditetapkan oleh pihak Puskesmas. Sedangkan guru UKS masih melakukan kegiatan UKS berdasarkan kegiatan rutin UKS dari Puskesmas saat berkunjung ke sekolah. Kemitraan antara Puskesmas dan sekolah belum terlaksana dengan optimal. Hubungan kemitraan antara Puskesmas dan sekolah belum mengacu pada prinsip kemitraan yang sebenarnya, masih sebatas kerjasama dalam hal pelaksanaan kegiatan trias UKS yang rutin dari Puskesmas.

Bagi Dinas Kesehatan dan Dinas Pendidikan, perlu meninjau kembali untuk penilaian kinerja UKS di sekolah saat dilaksanakan kegiatan lomba sekolah sehat. Perlu juga ditinjau ulang untuk pemberian reward bagi guru-guru UKS dan petugas Puskesmas yang mengelola UKS. Hal tersebut bisa dengan pemberian honorarium ataupun dengan penambahan nilai angka kredit point fungsional guru dan fugsional tenaga kesehatan.

\section{Ucapan Terima Kasih}

Peneliti mengucapkan terima kasih atas pendanaan Kementerian Riset Teknologi dan Pendidikan Tinggi Tahun Anggaran 2019.

\section{KEPUSTAKAAN}

1. Notoatmodjo S. Promosi Kesehatan Teori dan Aplikasi. Jakarta: Rineka Cipta; 2010.
2. Kemdikbud. Pedoman Pembinaan dan Pengembangan UKS/M. Jakarta: Direktorat Jenderal Pendidikan Dasar dan Menengah; 2018.

3. WHO. World Malaria Report 2018. Genewa; 2018.

4. Kemenkes RI. Laporan Riset Kesehatan Dasar. Jakarta; 2013.

5. DKK Bengkulu. Profil Kesehatan Bengkulu Tahun 2017. Bengkulu; 2018.

6. Kemenkes RI. Hari Malaria Sedunia, Pemerintah Perluas Wilayah Bebas Malaria. Jakarta: 2018.

7. Kemdikbud RI. Pusat Data Statistik Pendidikan. Jakarta; 2018.

8. Depkes RI. Pedoman Usaha Kesehatan Sekolah untuk Tenaga Kesehatan. Jakarta: Dirjen Binkesmas Depkes RI; 2011.

9. Kemdikbud RI. Laporan Kegiatan UKS. Kabupaten Seluma; 2018.

10. Hidayatulloh J. Pengaruh Pelatihan, Upah Insentif dan Masa Kerja terhadap Produktifitas Kerja Karyawan (Studi Kasus di PT. PG Krebet Baru Malang). J Ilm Fak Ekon dan Bisnis Univ Brawijaya. 2016;4(2).

11. Mangkuprawira ST. Manajemen Sumber Daya Manusia Stratejik. Bogor: Ghalia Indonesia; 2011.

12. Nurhayu MA. Pelaksanaan Trias Usaha Kesehatan Sekolah pada Tingkat Sekolah Dasar di Wilayah Kecamatan Tembalang Kota Semarang. J Kesehat Masy. 2018;

13. Karkada S. Concept of Health Promoting School. Manipal J Nurs Heal Sci. 2016;2:2.

14. Budiono MA. Peran UKS dalam Penyampaian Informasi Kesehatan ReprodUKSi terhadap Siswa SMP Negeri X di Surabaya. J Promkes. 2013;1(2):184-91.

15. Fridayanti D. Peran UKS (Usaha Kesehatan Sekolah) dalam Upaya Penanggulangan Obesitas pada Anak Usia Sekolah. J Heal Educ. 2016;1(2):8-14.

16. Ramawati D. Pelaksanaan Trias Usaha Kesehatan Sekolah di Sekolah Menengah Pertama di Wilayah Kecamatan Purwokerto Kabupaten Banyumas. J Keperawatan Soedirman. 2007;2(2):95-101.

17. Muzakkiroh U. Kemitraan Puskesmas dengan Sekolah Dasar dalam Kegiatan Usaha Kesehatan Sekolah (UKS) Studi Kasus di Wilayah Kerja Puskesmas Jabon Kec. Jombang Kab. Jombang Jawa Timur tahun 2004. J Bul Penelit Sist Kesehat. 2005;8(2):59-66.

18. Haming I. Kemitraan Sekolah dalam Usaha Perubahan Perilaku Siswa untuk Meningkatkan Motivasi Belajar IPS pada Siswa SMPN 3 Malusetasi Kabupaten Barru. Universitas Negeri Makasar; 2017.

19. Pertiwi KR. Pengembangan Model Pendidikan Kesehatan dalam Kurikulum Nasional Sekolah Dasar 
di Indonesia. Yogyakarta: Universitas Negeri Yogyakarta; 2012.

20. Fatmawati. Penerapan Fungsi Manajemen pada Program Usaha Kesehatan Sekolah di Sekolah Menengah Pertama. HIGEIA (Journal Public Heal Res Dev. 2018;3(2):179-89.

21. Abdullah F. Manajemen Pelaksana Program Stimulasi Deteksi dan Intervensi Dini Tumbuh Kembang (SDIDTK) terhadap Cakupan Balita dan Anak Prasekolah di Wilayah Kerja Puskesmas Kota
Ternate. J LINK. 2016;13(1):20-31.

22. Gurning FP. Pembinaan Puskesmas terhadap Pelaksanaan Program Usaha Kesehata Sekolah di Wilayah Kerja Puskesmas Padang Matinggi Kota Padang Sidempuan. JUMANTIK (Jurnal Ilm Penelit Kesehatan). 2017;3(1):65-71.

23. Yudho. Kemitraan dan Kepemimpinan dalam Implementasi Usaha Kesehatan Sekolah (UKS) di Kecamatan Mentawa Baru Ketapang Kabupaten Kota Waringin Timur. Yogyakarta; 2011. 